\title{
Rapid Communication Pathology \\ Generation of a cold-adapted PRRSV with a nucleotide substitution in the ORF5 and numerous mutations in the hypervariable region of NSP2
}

\author{
Van Tan Do (D), Hoai Thu Dao (D), Tae-Wook Hahn (D) * \\ College of Veterinary Medicine and Institute of Veterinary Science, Kangwon National University, \\ Chuncheon 24341, Korea
}

Received: Mar 27, 2020

Revised: Jul 23, 2020

Accepted: Sep 21, 2020

*Corresponding author:

Tae-Wook Hahn

Department of Veterinary Medicine, Kangwon

National University, 1 Kangwondaehak-gil,

Chuncheon 24341, Korea.

E-mail: twhahn@kangwon.ac.kr

(c) 2020 The Korean Society of Veterinary

Science

This is an Open Access article distributed under the terms of the Creative Commons Attribution Non-Commercial License (https:// creativecommons.org/licenses/by-nc/4.0) which permits unrestricted non-commercial use, distribution, and reproduction in any medium, provided the original work is properly cited.

ORCID iDs

Van Tan Do (iD

https://orcid.org/0000-0003-4512-7622

Hoai Thu Dao (1)

https://orcid.org/0000-0002-2797-9955

Tae-Wook Hahn (D)

https://orcid.org/0000-0002-3919-1153

Funding

None.

Conflict of Interest

The authors declare no conflicts of interest.

Author Contributions

Conceptualization: Do VT, Dao HT, Hahn TW; Data curation: Do VT; Formal analysis: Do VT, Dao HT; Investigation: Do VT, Dao HT; Methodology: Do VT, Dao HT, Hahn TW;

\section{ABSTRACT}

A cold-adapted porcine reproductive and respiratory syndrome virus (CA-VR2332) was generated from the modified live virus strain VR2332. CA-VR2332 showed impaired growth when cultured at $37^{\circ} \mathrm{C}$ with numerous mutations $\left({ }^{\mathrm{S}} 731^{\mathrm{F}},{ }^{\mathrm{E}} 819^{\mathrm{D}}\right.$, ${ }^{\mathrm{G}} 975^{\mathrm{E}}$, and $\left.{ }^{\mathrm{D}} 1014^{\mathrm{N}}\right)$ in the hypervariable region of the NSP2, in which the mutation ${ }^{\mathrm{S}} 731^{\mathrm{F}}$ might play a vital role in viral replication at $30^{\circ} \mathrm{C}$. Conserved amino acid sequences of the GP5 protein suggests that CAVR2332 is a promising candidate for producing an effective vaccine against PRRSV infection. Further studies on replication and immunogenicity in vivo are required to evaluate the properties of CA-VR2332.

Keywords: Porcine reproductive and respiratory syndrome; cold-adapted; GP5; hypervariable region; NSP2

\section{INTRODUCTION}

Porcine reproductive and respiratory syndrome (PRRS) was first reported in the USA in 1987 and in Europe in 1990 [1]. It is caused by the porcine reproductive and respiratory syndrome virus (PRRSV), which is an RNA virus of the order Nidovirales, family Arteriviridae, genus Aterivirus [1]. PRRSV is approximately $15 \mathrm{~kb}$ in size, composed of at least nine overlapping open reading frames (ORFs). ORFs 2-5 encode glycosylated membrane proteins GP2-GP5, ORF6 encodes a nonglycosylated membrane protein, and ORF7 encodes the nucleocapsid protein [2]. ORF1a and ORF1b form polyprotein pp1a and the large polyprotein pp1ab, respectively [3]. Among these proteins, GP5 plays an important role in viral infectivity and induces protective antibodies in the host [2]. Nonstructural protein 2 (NSP2), one of the proteins encoded by ORF1a, is the most variable and is involved in the regulation of viral replication and transcription [4].

PRRS is considered one of the most economically important swine disease, causing annually losses of more than $\$ 660$ million in the USA, more than $€ 650,000$ in Europe [5], and colossal economic losses to the swine industry in China and Asian countries [6]. Several inactivated vaccines and modified live virus (MLV) vaccines are licensed to combat infection 
Project administration: Hahn TW; Supervision: Hahn TW; Validation: Do VT, Hahn TW; Writing - original draft: Do VT; Writing - review \& editing: Do VT, Hahn TW. by PRRSV. Inactivated PRRS vaccines improve reproductive performance, but the immune response is often delayed and is controversial [7]. MLV vaccines increase pig farrowing and weaning rates, and improve growth performance, but their tendency to revert to virulence is a major concern [8]. MLV vaccines can get into the target organs and provoke diseases upon reversion of virulence, but cold-adapted vaccines do not replicate at body temperature and do not induce diseases. Thus, we aimed to address the safety concern of MLV PRRS vaccines by generation of a cold-adapted attenuated strain that would show impaired growth at body temperature $\left(37^{\circ} \mathrm{C}\right)$, and would not pose a threat. Numerous studies have been conducted to generate cold-adapted attenuated avian influenza virus vaccines, and these have identified promising candidate vaccines. A live cold-adapted H9N2 influenza virus candidate vaccine conferred protection of chickens from challenges with homologous and heterologous H9N2 viruses [9]. A cold-adapted attenuated porcine epidemic diarrhea virus (PEDV) provided durable lactogenic immunity and conferred passive protection to litters against PEDV infection demonstrating a live vaccine in maternal vaccination strategies [10]. Here, we generated a cold-adapted attenuated PRRSV and analyzed the changes in nucleotide and deduced amino acid sequences of GP5 and in the hypervariable region of NSP2.

\section{MATERIALS AND METHODS}

\section{Generation of a cold-adapted PRRSV}

To generate a cold-adapted PRRSV, MARC-145 cells were serially passaged at gradually reducing incubating temperatures from $37^{\circ} \mathrm{C}$ to $27^{\circ} \mathrm{C}$ using Dulbecco's Modified Eagle's Medium (DMEM; Gibco, Ireland) containing 10\% fetal bovine serum (FBS; Gibco), and 1\% antibiotic-antimycotic (Gibco). As a result, MARC-145 cells could adapt and grow well at $30^{\circ} \mathrm{C}$. A cold-adapted PRRSV was developed by inoculation of an attenuated modified live PRRSV vaccine strain VR2332 (MLV VR2332; Ingelvac PRRS; Boehringer Ingelheim, USA), on MARC-145 cells in DMEM containing 5\% FBS and 1\% antibiotic-antimycotic at temperatures ranging from $37^{\circ} \mathrm{C}$ to $30^{\circ} \mathrm{C}$. MLV VR2332 was incubated on MARC- 145 cells at $37^{\circ} \mathrm{C}$ until $>80 \%$ of the cells showed CPE, and harvested by three cycles of freezing and thawing. In the same manner, the virus was passaged at temperatures of $35^{\circ} \mathrm{C}, 33^{\circ} \mathrm{C}, 31^{\circ} \mathrm{C}$, and $30^{\circ} \mathrm{C}$.

\section{Plaque assay}

Plaque assays were performed to determine plaque-forming units (PFUs) of cold-adapted VR2332 (CA-VR2332) at $30^{\circ} \mathrm{C}$ or $37^{\circ} \mathrm{C}$ separately as described by Kim et al. [11] with modifications. Briefly, MARC-145 cells were seeded in a 24-well plate at a density of $1 \times 10^{5}$ cells/well one day before the assay. Cells were infected with serial 10-fold dilutions of virus (starting with the original virus at an equal multiplicity of infection of 1 ) for $1 \mathrm{~h}$ at $30^{\circ} \mathrm{C}$ or $37^{\circ} \mathrm{C}$. After removing the inoculum, the cells were then overlaid with DMEM containing $0.4 \%$ SeaPlaque Agarose (Lonza, Switzerland) and $5 \%$ FBS, followed by incubation at $30^{\circ} \mathrm{C}$ or $37^{\circ} \mathrm{C}$, $5 \% \mathrm{CO}_{2}$ for $5-7$ days. The plaques were visualized by fixation with $8 \%$ formaldehyde and stained with $1 \%$ crystal violet [11].

\section{Sequence alignment}

Ten individual CA clones were selected and passaged at $30^{\circ} \mathrm{C}$ an additional 10 times. Three of the 10 clones showing higher viral titers were selected for genome analysis. The full-length ORF5 and the hypervariable region of NSP2 for nucleotides 2158-3177 and the deduced amino acids 720-1059 (based on the full genome sequence of the MLV VR2332) were sequenced in both directions and compared using the ClustalX 2.0 program (http://www.clustal.org). 


\section{RESULTS}

\section{Generation of CA-VR2332}

The MLV VR2332 was inoculated on MARC-145 cells at gradually reducing incubating temperature from $37^{\circ} \mathrm{C}$ to $30^{\circ} \mathrm{C}$. CA-VR2332 clones were generated after 10 passages at $30^{\circ} \mathrm{C}$ and passaged 10 times more on MARC- 145 cells at $30^{\circ} \mathrm{C}$ to produce a high viral titer of $10^{6.5} \mathrm{TCID}_{50} / \mathrm{mL}$.

CA-VR2332 reached $10^{6.2} \mathrm{PFU} / \mathrm{mL}$ at $30^{\circ} \mathrm{C}$ but reduced forming PFU to $10^{4.2} \mathrm{PFU} / \mathrm{mL}$ at $37^{\circ} \mathrm{C}$. No PFUs were developed by the MLV VR 2332 and control cells at $30^{\circ} \mathrm{C}$. In contrast, the MLV VR2332 resulted in $10^{7} \mathrm{PFU} / \mathrm{mL}$ and formed bigger plaques at $37^{\circ} \mathrm{C}$ (Fig. 1). CA-VR2332 showed a 100 -fold reduction in PFUs when incubated at $37^{\circ} \mathrm{C}$ compared with that at $30^{\circ} \mathrm{C}$. Thus, CA-VR2332 showed impaired growth when cultured at normal body temperature $\left(37^{\circ} \mathrm{C}\right)$, suggesting the successful generation of CA-VR2332.

\section{Sequence comparison of MLV VR2332 and CA-VR2332}

To investigate how cold adaptation caused the change in sequences of ORF5 encoding GP5 and the hypervariable region of NSP2, 10 cold-adapted clones were harvested and propagated on MARC-145 cells at $30^{\circ} \mathrm{C}$ individually for an additional 10 passages. Three CA-VR2332 clones (CA3, CA8, and CA9) with high viral titers at passage 30 were selected for sequencing and comparison with the MLV VR2332. As shown in Fig. 2 A and B, cold adaptation caused one nucleotide substitution ${ }^{\mathrm{C}} 251^{\mathrm{T}}$, but no change in the deduced amino acid sequences of GP5 of all three CA-VR2332 clones was seen. Notably, sequence alignment of the hypervariable region of NSP2 showed that all three clones contained the same nucleotide and amino acid substitutions. Changes in nucleotide sequences were observed at five positions (Fig. 3A), in which one mutation did not cause substitution of amino acid 725. Four substitutions of amino acids occurred at residues ${ }^{\mathrm{S}} 731^{\mathrm{F}},{ }^{\mathrm{E}} 819^{\mathrm{D}},{ }^{\mathrm{G}} 975^{\mathrm{E}}$, and ${ }^{\mathrm{D}} 1014^{\mathrm{N}}$ (Fig. 3B).

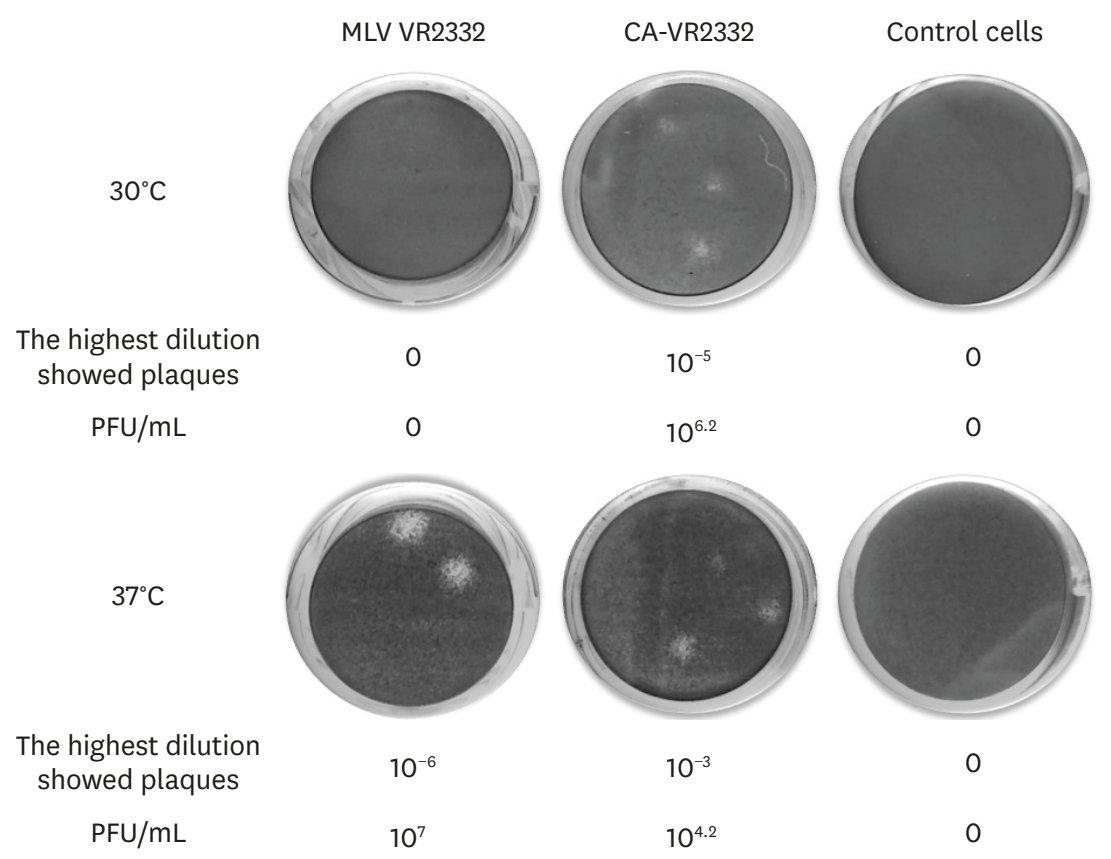

Fig. 1. Plaque-forming units of the MLV VR2332 and CA-VR2332 at $30^{\circ} \mathrm{C}$ or $37^{\circ} \mathrm{C}$. $\mathrm{PFU}$, plaque-forming unit. 
A

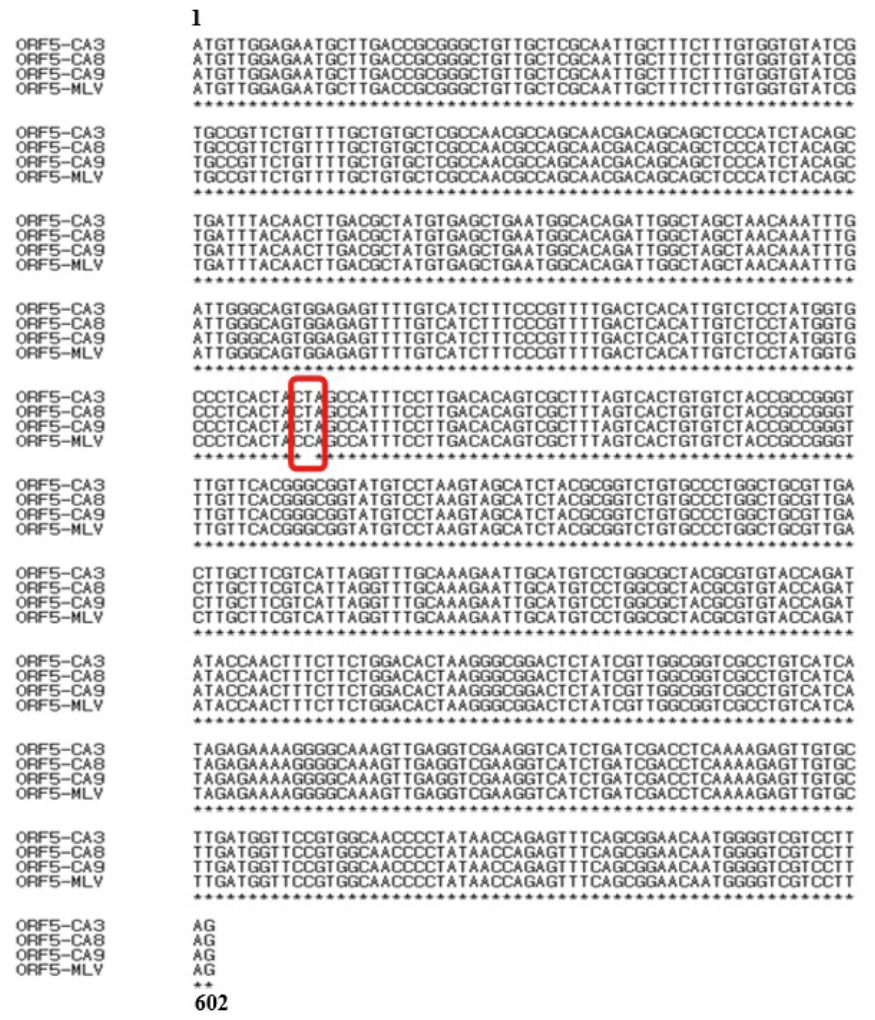

B

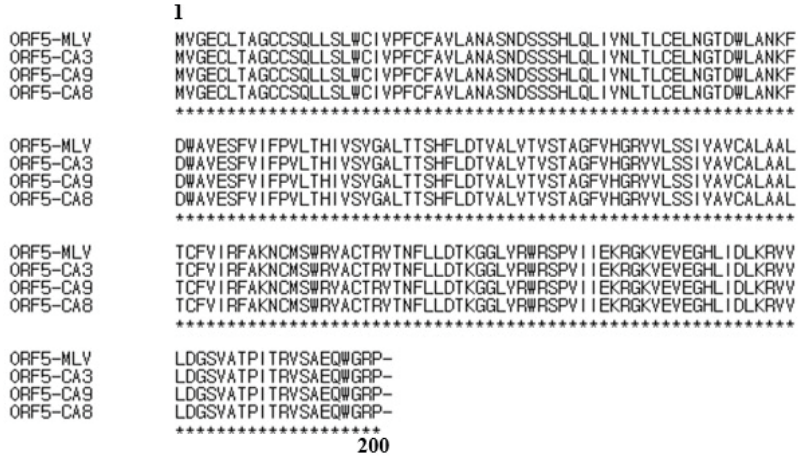

Fig. 2. Nucleotide sequence alignment of ORF5 (A), and the deduced amino acid sequence comparison of GP5 (B) of the MLV VR2332 and CA-VR2332 clones. Nucleotide substitutions are shown in the red box. No substitutions in the amino acid sequences of GP5 were observed.

\section{DISCUSSION}

The ORF5 encodes GP5, which is the main structural protein of PRRSV. GP5 has high immunogenicity and induces neutralizing antibodies in the host [2]. An et al. [12] generated an attenuated PRRSV strain HuN4-F112 by passaging a virulent strain on MARC-145 cells 112 times at $37^{\circ} \mathrm{C}$, and compared the GP5 sequences of the virulent and attenuated strains. An amino acid substitution $\left({ }^{(} 196^{\mathrm{R}}\right)$ was detected at passage 20 and an additional amino acid change $\left({ }^{\mathrm{N}} 34^{\mathrm{D}}\right)$ occurred at passage 65 . No further change in GP5 sequence was observed until passage 112. In the present study, sequencing showed one nucleotide change, but it did not cause any change in the deduced amino acid sequences of GP5 compared with the MLV VR2332 (Fig. 2B). Thus, cold adaptation did not appear to affect the amino acid sequence of GP5.

ORF1a and ORF1b encode a large polyprotein containing cleavage products involving viral transcription and replication, in which NSP1, 2, 3, 4, and 5 are encoded by ORF1a [13]. NSP2 is the most variable nonstructural protein, primarily in its middle region, sharing $32 \%$ amino acid sequences among subtypes [13]. Faaberg et al. [14] indicated that amino acids 727-813 of NSP2 were important for PRRSV replication in vivo. Deletion of these amino acids in PRRSV produced a significant decrease in the enlargement of lymph nodes in infected pigs compared with full-length PRRSV VR2332. In the present study, four substitutions of amino acids occurred at residues ${ }^{\mathrm{S}} 731^{\mathrm{F}},{ }^{\mathrm{E}} 819^{\mathrm{D}},{ }^{\mathrm{G}} 975^{\mathrm{E}}$, and ${ }^{\mathrm{D}} 1014^{\mathrm{N}}$ (Fig. 3B), with mutation ${ }^{\mathrm{S}} 731^{\mathrm{F}}$ in an important sequence (amino acids 727-813), suggesting that this mutation could play a vital role in replication of the MLV VR2332 at $30^{\circ} \mathrm{C}$. 
A

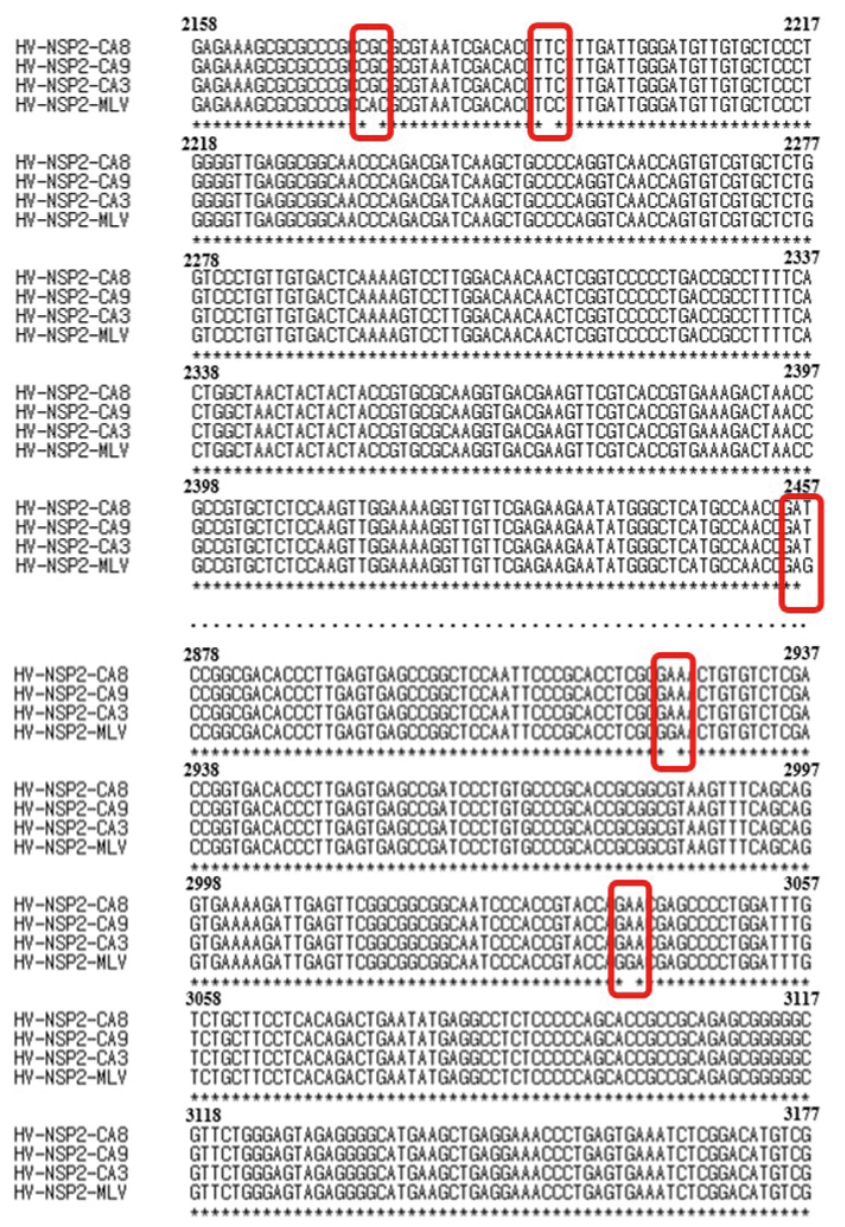

\section{B}

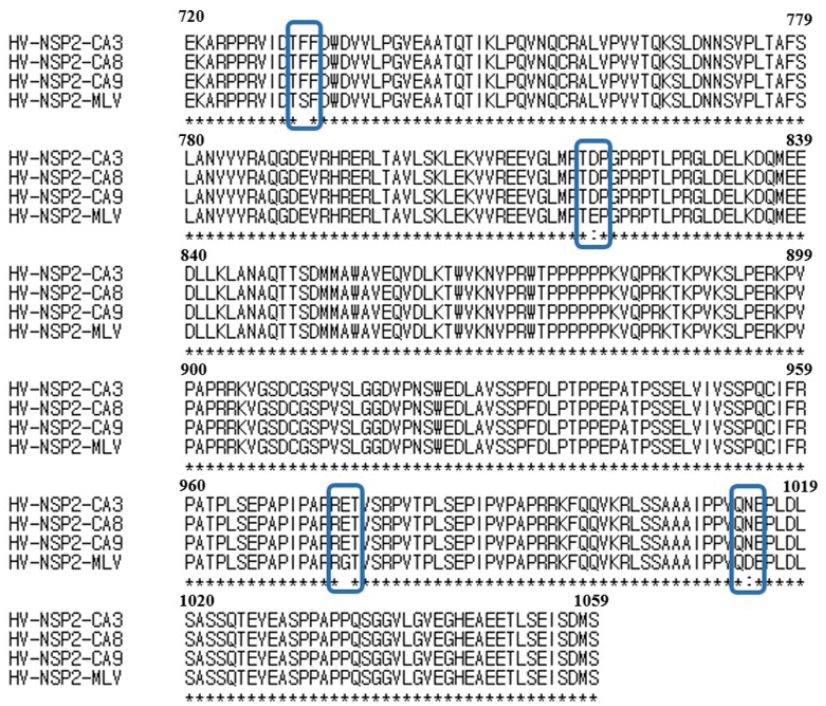

Fig. 3. Nucleotide sequence alignment (A), and the deduced amino acid sequence comparison (B) of the hypervariable region of NSP2 of the MLV VR2332 and CAVR2332 clones. Nucleotide substitutions are shown in the red boxes, and substitutions of deduced amino acids are shown in the blue boxes.

In a previous study, attenuation of virulent PRRSV strains on MARC-145 cells at $37^{\circ} \mathrm{C}$ caused eight mutations in NSP2 $\left({ }^{\mathrm{H}} 401^{\mathrm{R}},{ }^{\mathrm{T}} 477^{\mathrm{I}},{ }^{\mathrm{D}} 799^{\mathrm{N}},{ }^{\mathrm{V}} 894^{\mathrm{A}},{ }^{\mathrm{S}} 1009^{\mathrm{P}},{ }^{\mathrm{N}} 1090^{\mathrm{S}},{ }^{\mathrm{C}} 1166^{\mathrm{S}}\right.$, and $\left.{ }^{\mathrm{T}} 1481^{\mathrm{A}}\right)$, in which the mutation ${ }^{\mathrm{D}} 799^{\mathrm{N}}$ is within a sequence that is important for viral replication [12]. Thus, mutations in NSP2 occurred not only in this important sequence but also in the full-length protein needed for viral replication and attenuation. In our study, progressive cold adaptation caused mutations in this key sequence and in the hypervariable sequence of NSP2. These mutations occurred at the same positions among three of the CA clones. Thus, mutations in this highly variable region of NSP2, especially amino acids 727-813, have significant effects not only in replication and attenuation but also in cold adaptation of PRRSV.

To our knowledge, this is the first study to generate a cold-adapted attenuated PRRSV. We successfully generated CA-VR2332 and the changes in the sequences of nucleotides and amino acids of GP5 protein and the hypervariable region in NSP2 were observed. There is a need for further studies on the replication and immunogenicity of this cold-adapted PRRSV in pigs. 


\section{REFERENCES}

1. Wensvoort G, Terpstra C, Pol JM, ter Laak EA, Bloemraad M, de Kluyver EP, et al. Mystery swine disease in the Netherlands: the isolation of Lelystad virus. Vet Q. 1991;13(3):121-130.

PUBMED | CROSSREF

2. Dea S, Gagnon CA, Mardassi H, Pirzadeh B, Rogan D. Current knowledge on the structural proteins of porcine reproductive and respiratory syndrome (PRRS) virus: comparison of the North American and European isolates. Arch Virol. 2000;145(4):659-688. PUBMED | CROSSREF

3. van Aken D, Zevenhoven-Dobbe J, Gorbalenya AE, Snijder EJ. Proteolytic maturation of replicase polyprotein pp1a by the nsp4 main proteinase is essential for equine arteritis virus replication and includes internal cleavage of nsp7. J Gen Virol. 2006;87(Pt 12):3473-3482. PUBMED | CROSSREF

4. Lee SC, Choi HW, Nam E, Noh YH, Lee S, Lee YJ, et al. Pathogenicity and genetic characteristics associated with cell adaptation of a virulent porcine reproductive and respiratory syndrome virus nsp2 DEL strain CA-2. Vet Microbiol. 2016;186:174-188. PUBMED | CROSSREF

5. Montaner-Tarbes S, Del Portillo HA, Montoya M, Fraile L. Key gaps in the knowledge of the porcine respiratory reproductive syndrome virus (PRRSV). Front Vet Sci. 2019;6:38. PUBMED | CROSSREF

6. Han J, Zhou L, Ge X, Guo X, Yang H. Pathogenesis and control of the Chinese highly pathogenic porcine reproductive and respiratory syndrome virus. Vet Microbiol. 2017;209:30-47. PUBMED | CROSSREF

7. Papatsiros VG, Alexopoulos C, Kritas SK, Koptopoulos G, Nauwynck HJ, Pensaert MB, et al. Long-term administration of a commercial porcine reproductive and respiratory syndrome virus (PRRSV)-inactivated vaccine in PRRSV-endemically infected sows. J Vet Med B Infect Dis Vet Public Health. 2006;53(6):266-272. PUBMED | CROSSREF

8. Alexopoulos C, Kritas SK, Kyriakis CS, Tzika E, Kyriakis SC. Sow performance in an endemically porcine reproductive and respiratory syndrome (PRRS)-infected farm after sow vaccination with an attenuated PRRS vaccine. Vet Microbiol. 2005;111(3-4):151-157. PUBMED | CROSSREF

9. Wei Y, Qi L, Gao H, Sun H, Pu J, Sun Y, et al. Generation and protective efficacy of a cold-adapted attenuated avian H9N2 influenza vaccine. Sci Rep. 2016;6(1):30382-30382. PUBMED | CROSSREF

10. Won H, Lee DU, Jang G, Noh YH, Lee SC, Choi HW, et al. Generation and protective efficacy of a coldadapted attenuated genotype 2b porcine epidemic diarrhea virus. J Vet Sci. 2019;20(4):e32. PUBMED | CROSSREF

11. Kim H, Kim HK, Jung JH, Choi YJ, Kim J, Um CG, et al. The assessment of efficacy of porcine reproductive respiratory syndrome virus inactivated vaccine based on the viral quantity and inactivation methods. Virol J. 2011;8(1):323-323. PUBMED | CROSSREF

12. An TQ, Tian ZJ, Zhou YJ, Xiao Y, Peng JM, Chen J, et al. Comparative genomic analysis of five pairs of virulent parental/attenuated vaccine strains of PRRSV. Vet Microbiol. 2011;149(1-2):104-112. PUBMED | CROSSREF

13. Han J, Liu G, Wang Y, Faaberg KS. Identification of nonessential regions of the nsp2 replicase protein of porcine reproductive and respiratory syndrome virus strain VR-2332 for replication in cell culture. J Virol. 2007;81(18):9878-9890.

PUBMED | CROSSREF

14. Faaberg KS, Kehrli ME Jr, Lager KM, Guo B, Han J. In vivo growth of porcine reproductive and respiratory syndrome virus engineered nsp2 deletion mutants. Virus Res. 2010;154(1-2):77-85.

PUBMED | CROSSREF 